Abstracta Iranica Abstracta Iranica

Revue bibliographique pour le domaine irano-aryen

Volume 25 | 2004

Comptes rendus des publications de 2002

\title{
Twenty Years of Islamic revolution. Political and Social Transition in Iran since 1979. New York, Syracuse University Press, 2002, 193 p.
}

\section{Bernard Hourcade}

\section{OpenEdition}

1 Journals

\section{Édition électronique}

URL : http://journals.openedition.org/abstractairanica/5152

DOI : 10.4000/abstractairanica.5152

ISSN : 1961-960X

Éditeur :

CNRS (UMR 7528 Mondes iraniens et indiens), Éditions de l'IFRI

\section{Édition imprimée}

Date de publication : 15 mai 2004

ISSN : 0240-8910

Référence électronique

Bernard Hourcade, "Twenty Years of Islamic revolution. Political and Social Transition in Iran since 1979. New York, Syracuse University Press, 2002, 193 p. », Abstracta Iranica [En ligne], Volume 25 | 2004 document 324, mis en ligne le 15 mars 2006, consulté le 25 septembre 2020. URL : http://

journals.openedition.org/abstractairanica/5152; DOI : https://doi.org/10.4000/abstractairanica.5152

Ce document a été généré automatiquement le 25 septembre 2020.

Tous droits réservés 


\section{Twenty Years of Islamic revolution. Political and Social Transition in Iran since 1979. New York, Syracuse University Press, 2002, 193 p.}

\section{Bernard Hourcade}

Ce livre réunit les analyses présentées en 1999 dans un cycle de conférences, par des spécialistes non américains de l'Iran, notamment iraniens et français. Un tour d'horizon complet de la situation iranienne est ainsi réalisé par les meilleurs spécialistes de chaque domaine, ce qui permet à travers ce livre de disposer d'une présentation synthétique et claire de la situation de l'Iran vingt ans après la révolution islamique. Farhad Khosrokhavar (cf. c.r. $n^{\circ} 305$ ) analyse les mouvements sociaux, Mehdi Moslem (cf. c.r. $n^{\circ} 328$ ) la vie politique, Marcus Gerhardt (cf. c.r. $n^{\circ} 303$ ) le sport, Azadeh Kian-Thiébaut (cf. c.r. $n^{\circ}$ 306) et Ziba Mir-Hosseyni (cf. c.r. n 311) la situation des femmes, Mostafa Azkia (cf. c.r. $n^{\circ}$ 301) le monde rural, Jalil Roshandel (cf. c.r. $n^{\circ} 332$ ), Eric Rouleau (cf. c.r. $n^{\circ} 333$ ) et Eric Hooglund (cf. c.r. $n^{\circ}$ 323) respectivement la politique étrangère, la politique européenne et le Golfe Persique.

\section{INDEX}

Thèmes : 13.1. Iran 
AUTEURS

BERNARD HOURCADE

CNRS - Paris 